\title{
Herbivory drives kelp recruits into 'hiding' in a warm ocean climate
}

\author{
João N. Franco ${ }^{1,2, *}$, Thomas Wernberg ${ }^{3}$, Iacopo Bertocci ${ }^{1}$, Pedro Duarte $^{4}$, \\ David Jacinto $^{5}$, Nuno Vasco-Rodrigues ${ }^{6}$, Fernando Tuya ${ }^{7}$ \\ ${ }^{1}$ CIIMAR/CIMAR, Centro Interdisciplinar de Investigação Marinha e Ambiental, Rua dos Bragas 289, 4050-123 Porto, Portugal \\ ${ }^{2}$ Departamento de Biologia, Faculdade de Ciências, Universidade do Porto, Rua do Campo Alegre s/n, 4150-181 Porto, Portugal \\ ${ }^{3}$ School of Plant Biology \& UWA Oceans Institute (M470), University of Western Australia, Crawley, Western Australia 6009, \\ Australia \\ ${ }^{4}$ Norwegian Polar Institute, Fram Centre, Post Box 6606 Langnes, 9296 Tromsø, Norway \\ ${ }^{5}$ MARE - Marine and Environmental Sciences Centre, Laboratório de Ciências do Mar, Universidade de Évora, Apartado190, \\ 7521-903 Sines, Portugal \\ ${ }^{6}$ MARE - Marine and Environmental Sciences Centre, ESTM, Polytechnic Institute of Leiria, 2520-641 Peniche, Portugal \\ ${ }^{7}$ Grupo en Biodiversidad y Conservación, Universidad de Las Palmas de Gran Canaria, Canary Islands, Spain
}

ABSTRACT: Assessing effects of herbivory across broad gradients of varying ocean climate conditions and over small spatial scales is crucial for understanding its influence on primary producers. Effects of herbivory on the distribution and abundance of kelp recruits were examined experimentally at two regions under contrasting ocean climate. Specifically, the abundance and survivorship of kelp recruits and the abundance of macro-herbivores were compared between a 'cool' and a 'warm' region in northern and central Portugal, respectively. In each region, the abundance of kelp recruits and the intensity of grazing were compared between habitats of different topography within reefs (open reef vs. crevices). Compared to the 'warm' region, the abundance of kelp recruits was 3.9 times greater in the 'cool' region, where $85 \%$ of recruits were found in open reef habitats. In contrast, $87 \%$ of recruits in the 'warm' region were restricted to crevices. The 'warm' region had 140 times greater abundances of sea urchins, 45 times more herbivorous fish and 4.1 times more grazing marks on kelp recruits than the 'cool' region. Grazing assays showed ca. 50 times higher rates of kelp biomass consumption, mainly by fishes, and zero survivorship of kelp recruits in the 'warm' relative to the 'cool' region. This study suggests both temperature and herbivores affect abundances of kelp recruits across latitudes, and demonstrates how herbivores affect their distribution at local scales, driving kelp recruits into 'hiding' in crevices under intense herbivory. Consequently, where net recruitment success is compromised by herbivory, the persistence of kelps will be contingent on availability of topographical refuges.

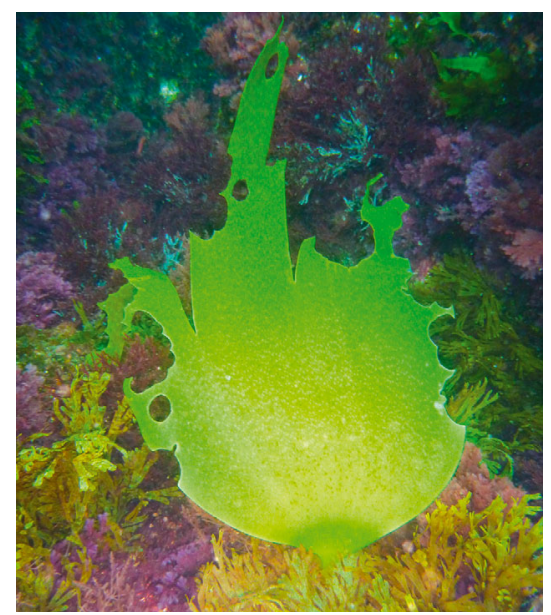

Outside the shelter of crevices, kelp recruits are exposed to consumption by fishes, as seen on this Sacchoriza polyschides with crescent-shaped fish bite marks

Photo: Thomas Wernberg

KEY WORDS: Atlantic Ocean - Portugal - Habitat complexity $\cdot$ Climate $\cdot$ Kelp forests $\cdot$ Grazing $\cdot$ Range limit

Resale or republication not permitted without written consent of the publisher

\section{INTRODUCTION}

Herbivory is a key ecological process shaping the structure and dynamics of biological communities (Schmitz et al. 2004, Poore et al. 2012, Bennett et al. 
2015). Herbivory affects primary producers in all systems, including lakes, forests, grasslands, kelp forests, coral reefs and marine systems (Shurin et al. 2002, Steneck et al. 2002), altering their biomass, productivity, physical structure and diversity over a range of spatial and temporal scales (Stachowicz et al. 2007). With grazing rates up to 3 times greater than in terrestrial systems (Cyr \& Pace 1993), herbivory is particularly influential in driving patterns of community structure in aquatic systems. In addition, the strength of predator-prey interactions that alter the abundance, biomass and productivity of primary producers indirectly via trophic cascades is stronger in aquatic compared to terrestrial systems (Shurin et al. 2002).

The intensity of herbivory is hypothesized to decrease from tropical to temperate regions of the world's oceans (Gaines \& Lubchenco 1982, Bolser \& Hay 1996). Support for this hypothesis includes decreasing abundances and diversity of herbivores towards colder waters (Meekan \& Choat 1997, Floeter et al. 2005), stronger chemical defenses of algae at lower latitudes (Craft et al. 2013), effects of water temperature on herbivore-plant interactions (see below, this section) and herbivore digestive physiology due to reduction in digestion efficiency (Gaines \& Lubchenco 1982). Warmer water temperatures increase the metabolic processes favoring higher consumption rates of herbivores and growth of primary producers, and consumption rates might increase faster than production (Brown et al. 2004), potentially resulting in a negative balance between production and consumption. Studies aimed at empirically testing whether rates of herbivory change across latitude are, however, limited, particularly for subtidal environments (but see e.g. Moles et al. 2011). Yet, while some earlier results support the progressive decrease in herbivory intensity with increasing latitude (Schemske et al. 2009), a recent meta-analysis of 613 field experiments (Poore et al. 2012), in most cases carried out in intertidal systems, revealed that on a global scale the impact of marine herbivores on primary producers does not change with latitude. Not surprisingly, such inconsistent findings have prevented the formulation of general and widely accepted explanations for the importance and nature of such biotic interactions and for their changes with latitude (Cahill et al. 2014). Moreover, Poore et al. (2012) emphasized the importance of producer traits, including both the identity and morphology, as responsible for highly variable grazing impacts on different organisms. In this context, large brown seaweeds, such as kelps, are among the species most impacted by herbivores within temperate marine vegetation.
Kelps are 'foundation' species on many shallow rocky coasts at polar and temperate latitudes that are directly influenced by temperature, nutrient and light availability (Bartsch et al. 2008). In many systems, herbivory plays a major role in driving patterns of abundance and distribution of kelps, with subsequent consequences for the ecological performance of kelp forests (Steneck et al. 2002).

There is widespread evidence that herbivores (e.g. sea urchins) can eradicate kelps at both large and small spatial scales (Ling et al. 2010), producing large 'barren' areas that replace entire kelp forests, or creating gaps within kelp canopies. Moreover, there is a growing body of literature showing that tropical fish communities are expanding to temperate regions with negative ecological impacts (Wernberg et al. 2013, Vergés et al. 2014, Bennett et al. 2015).

Kelp distribution and abundance can also be influenced by biotic and abiotic processes operating at small, local, scales, i.e. from a few centimeters to tens of meters, through alterations in reef architecture. In spite of the documented importance of reef topography for structuring reef-associated assemblages (e.g. fishes) on temperate reefs (Tuya et al. 2011), little is known about its influence on macroalgal assemblages and kelps in particular (Toohey et al. 2007). Habitats or environmental factors that enhance resistance and/or resilience (spatially and/or temporally) in communities that are exposed to biophysical disturbances can be considered as 'refugia' (Sedell et al. 1990). In this context, substratum topography offers protection to different organisms against multiple types of disturbance, as demonstrated by accumulating studies from terrestrial (Reader 1992) and aquatic systems (Bergey 2005, Brandl et al. 2014). For example, encrusting algae of the genus Hildenbrandia are successful against herbivory because propagules have a tendency to grow out from small cracks and crevices inaccessible to grazers (Underwood 1980). Analogously, Bergey (2005) described the importance of crevices to increase algal recovery after disturbance, and Brandl et al. (2014) indicated the crucial role of crevices for early life stages of both coral and macroalgal populations. Nevertheless, to our knowledge, no study has tested the role of topographical refugia for kelp recruit survival.

The coast of continental Portugal extends for more than $800 \mathrm{~km}$ and is a recognized interface between cold-temperate and warm-temperate species (Lima et al. 2007, Tuya et al. 2012). Recently, Tuya et al. (2012) described a biogeographic discontinuity in the composition and structure of reef-associated algal and fish assemblages between northern (a 'cool' 
region) and central and southern Portugal (a 'warmtemperate' region). Importantly, kelps (Laminaria ochroleuca, Laminaria hyperborea and Saccorhiza polyschides) have shown abrupt latitudinal clines in their abundances across continental Portugal, being common in the north, at very low densities in central Portugal, and practically absent in southern Portugal (Assis et al. 2009, Tuya et al. 2012). In this study, we took advantage of the varying ocean climate across continental Portugal to assess the influence of herbivores on the abundance of juvenile kelps at warmer compared to cooler regions. The differences in ocean climate could modify the importance of habitat topography (i.e. the local availability of refuges) as a driver of the local distribution of kelp recruits through protection against herbivores. Specifically, we tested the hypotheses that (1) the abundance of macro-grazers and the intensity of herbivory (quantified in terms of bite marks and consumption of juvenile kelps) would be lower in northern than central Portugal; (2) kelp recruits would be more abundant in northern than central Portugal; (3) rates of herbivory would be lower in crevices than in open reef habitats. Overall, the integration of these hypotheses led to the prediction that herbivory might not only provide a major contribution to macroecological differences in the abundance of early life-stages of kelps at large spatial scales, but also represent a key driver of their reef-scale distribution.

\section{MATERIALS AND METHODS}

Study area. This study was conducted at Peniche $\left(\mathrm{PEN}, 39.2^{\circ} \mathrm{N}, 9.2^{\circ} \mathrm{W}\right.$ ) and Vila do Conde (VIL $41.2^{\circ} \mathrm{N}$, $8.46^{\circ} \mathrm{W}$ ), separated by ca. $250 \mathrm{~km}$ (ca. $2^{\circ}$ of latitude), in central and northern Portugal, respectively. This coastline is almost rectilinearly oriented from north to south, maintaining a similar overall exposure to dominant NW and W swells. The shore is characterised by extensive sandy beaches interspersed with limestone, sandstone, shale or granitic reefs in both the intertidal and the shallow subtidal. There are clear differences in ocean climate conditions between these 2 regions: VIL (mean winter and summer temperature: $\sim 13$ and $17^{\circ} \mathrm{C}$, respectively) has a mean annual SST of $\sim 1$ to $2^{\circ} \mathrm{C}$ lower than PEN (mean winter and summer temperature: $\sim 14$ and $18^{\circ} \mathrm{C}$, respectively). VIL (mean winter and summer chlorophyll a: $\sim 0.86$ and $1.20 \mathrm{mg} \mathrm{m}^{-3}$, respectively) has a mean annual chlorophyll $a$ of $\sim 1 \mathrm{mg} \mathrm{m}^{-3}$ higher than PEN (mean winter and summer: $\sim 0.50$ and $0.67 \mathrm{mg} \mathrm{m}^{-3}$, respectively) (Tuya et al. 2012). Northern Portugal is distinct, in terms of reef kelp coverage (>50\%) compared to central Portugal, where kelps are very sparse (Tuya et al. 2012, Pinho et al. 2015). Water temperatures considered lethal for the focal kelp species (Bartsch et al. 2008) are not reached in the studied region (see, for instance, SST data reported for northern and south-western Portugal by Bertocci et al. 2014). Within each region, replicate rocky reefs ( 1 km apart) were selected randomly at 6 to $11 \mathrm{~m}$ depth. All herbivore (sea urchins and fishes) surveys and grazing experiments were carried out over a period of 3 wk between mid-July and early August 2012 and 2013, as illustrated in detail in the corresponding sections below.

Kelp recruit abundance and grazing marks. The abundance of kelp (Laminaria spp. and Saccorhiza polyschides) recruits was estimated along 10 transects $(1 \times 0.2 \mathrm{~m})$ at each of 5 reefs within each region between 16 July and 8 August 2012. Sampling at each reef was stratified according to 'open reef' and 'crevices' to encompass these 2 habitats of contrasting reef topography (Vanderklift \& Kendrick 2004). Since species of juvenile kelp sporophytes are morphologically indistinguishable, particularly underwater, we were unable to establish the species identity of recruits. We collected a total of 234 kelp recruits (10 to $25 \mathrm{~cm}$ in total length): 69 from crevices and 165 from open reef habitat, for a semi-quantitative analysis of grazing marks. In the laboratory, recruits from each reef were photographed, the presence of grazing marks was quantified and each recruit was assigned to one of 3 categories: no grazing, light grazing $(<25 \%$ of tissue affected) and heavy grazing ( $>50 \%$ of tissue affected) (see Fig. S1 in the Supplement at www.int-res.com/articles/suppl/ m536p001_supp.pdf).

Kelp recruit survival. At each of 2 reefs within each region, starting on the 16 July 2012 in Peniche and on 6 August 2012 in Vila do Conde, 20 random kelp recruits were tagged by attaching a cable tie around the stipe of each individual (de Bettignies et al. 2013). Tagged individuals were collected after 1 mo to assess survival.

Rates of herbivory. Rates of herbivory were quantified in a kelp tethering experiment (Wernberg et al. 2006) between 16 July and 8 August 2012, allowing equal exposure of kelps to fishes and sea urchins. At each of 3 reefs within each location, 8 kelp recruits (10-20 cm in total length, 2.2-6.8 $\mathrm{g}$ wet weight) were attached to chains (6 per reef) by clothes pegs. At each reef, 3 chains ( $=24$ recruits) were deployed inside crevices, and 3 chains were deployed on adjacent open reef areas. Replicated chains were 
interspersed within ca. $500 \mathrm{~m}^{2}$ on each reef. The wet weight (ww; to the nearest $0.1 \mathrm{~g}$ after shaking off excess of water and blotting with paper) of each kelp recruit was measured at the beginning of the experiment and after $48 \mathrm{~h}$ of deployment. Because of the short deployment and overall calm sea conditions during experimentation, algal loss due to autogenic changes was assumed to be negligible relative to herbivory losses; previous tests using similar tethering experiments with kelps have shown that tissue losses are $<2 \%$ over a few days (Wernberg et al. 2006), meaning that the change in weight is considered as representative of the amount of tissue consumed by herbivores (Levenbach 2009). All kelp recruits were collected by hand at Mindelo $\left(41.1^{\circ} \mathrm{N}\right)$, a shallow-water reef location that easily supplied hundreds of recruits. In all cases, tethered kelps were deployed $<24 \mathrm{~h}$ after collection and were always maintained in aerated sea-water to minimize stress and damage. Using recruits of the same origin removed any potential influence of location-specific differences in biochemical composition (nutritive value or grazing deterrents).

Macro-herbivore abundance. From 16 July to 8 August 2012, and within the same period in 2013, all adult and sub-adult fishes were counted along 5 randomly oriented $25 \times 4 \mathrm{~m}$ belt transects at each of the 5 reefs within each region (Tuya et al. 2012). The number of Paracentrotus lividus, the most common sea urchin in continental Portugal (Jacinto et al. 2013), was counted along five $25 \times 1 \mathrm{~m}$ transects. Fishes were categorized according to their trophic affinities (Henriques et al. 2013; www.fishbase.org; see Table S1 in the Supplement). Herbivorous fishes were considered as those species able to consume algae, thus also including omnivorous species (Sala \& Zabala 1996, Horta et al. 2004).

Statistical analyses. Differences in the abundance of kelp recruits were tested by 3-way ANOVA, including the factors: Region (2 levels: PEN vs. VIL, fixed), Reef (5 levels, random and nested within regions) and Habitat (2 levels: open reef vs. crevices, fixed factor and orthogonal to the previous factors). Regions were considered fixed in our analyses, as these represented 'cool' and 'warm' ocean climates, respectively. Differences in the amount of kelp tissue consumed by macro-herbivores was analyzed by 4-way ANOVA, including: Region (2 levels) and Habitat (2 levels) as fixed factors, while Reef (3 levels, nested within regions) and Chain (3 levels, nested within regions, habitats and reefs) were treated as random factors. The abundance of herbivorous fishes and sea urchins was analyzed by 3-way
ANOVAs, including: Region (2 levels, fixed), Year (2 levels, random and nested within regions) and Reef (5 levels, random and nested within regions and years). Before each ANOVA, the assumption of homogeneity of variances was checked through a Cochran's $C$ test; only the abundance of herbivorous fishes had to be $\ln (\mathrm{x}+1)$ transformed to achieve homogeneous variances. When differences were found, a posteriori comparisons were carried out using pairwise Student-Newman-Keuls (SNK) tests (Underwood 1997). A chi-squared $\left(\chi^{2}\right)$ test was used to test for differences in the amount of grazing marks between regions and reef habitats. Kelp recruit survival was reported as percentage of lost individuals.

\section{RESULTS}

\section{Abundance and survival of kelp recruits}

Kelp recruit abundance was 3.9 times greater at VIL than PEN. Recruits at VIL were predominantly found in open reef habitats (Fig. 1). In contrast, the few kelp recruits at PEN were mainly found inside crevices (significant interaction Region $\times$ Habitat, $\mathrm{p}<$ 0.001; Cochran's test: $C=0.2664$ ) (Table 1, Fig. 1). There was zero survivorship of kelp recruits at PEN, where all tagged kelps disappeared (0\% survival), while the opposite was observed at VIL, where all tagged individuals were retrieved after 1 mo (100\% survival).

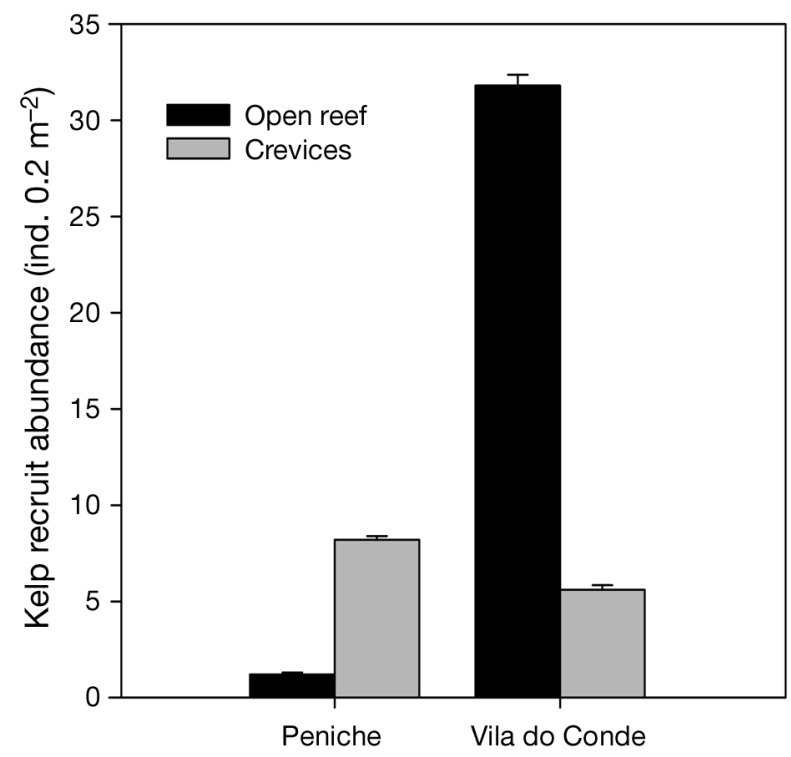

Fig. 1. Abundance of kelp recruits in each of two habitat types (open reef and crevices) at Peniche and Vila do Conde, Portugal (mean $+\mathrm{SE}, \mathrm{n}=10$ ) 
Table 1. Summary of ANOVAs on the abundance of herbivorous fishes, sea urchins and kelp recruits and grazing intensity on kelp recruits at Peniche (PEN) and Vila do Conde (VIL), Portugal, according to regions (PEN and VIL), years (2012 vs 2013), reefs, habitats (contrasting reef topography: 'open reef' and 'crevices') and chains. Student-Newman-Keuls (SNK) tests resolved significant differences for fixed factors

\begin{tabular}{|c|c|c|c|c|c|c|c|c|}
\hline \multirow[b]{2}{*}{ Source of variation } & \multicolumn{4}{|c|}{ Abundance of grazing fishes } & \multicolumn{4}{|c|}{ Abundance of sea urchins } \\
\hline & df & MS & $F$ & $\mathrm{p}$ & df & MS & $F$ & $\mathrm{p}$ \\
\hline Region & 1 & 117.08 & 0 & $<0.001$ & 1 & 12254.49 & 0 & $<0.001$ \\
\hline Year & 1 & 17.51 & 62.83 & $<0.001$ & 1 & 756.25 & 5.74 & 0.043 \\
\hline Reef(Region) & 8 & 1.65 & 5.94 & 0.01 & 8 & 1015.37 & 7.70 & 0.004 \\
\hline Region $\times$ Year & 1 & 32.26 & 115.74 & $<0.001$ & 1 & 650.25 & 4.93 & 0.049 \\
\hline Year × Reef(Region) & 8 & 0.27 & 0.33 & 0.95 & 8 & 131.85 & 2.30 & 0.028 \\
\hline Residual & 80 & 0.23 & & & 80 & 57.37 & & \\
\hline \multirow[t]{2}{*}{ SNK tests } & \multicolumn{4}{|c|}{$\begin{array}{c}\text { Region } \times \text { Year } \\
\text { PEN > VIL: both years }\end{array}$} & \multicolumn{4}{|c|}{$\begin{array}{c}\text { Region } \\
\text { PEN > VIL: both years }\end{array}$} \\
\hline & \multicolumn{4}{|c|}{ Grazing on kelp recruits } & \multicolumn{4}{|c|}{ Abundance of kelp recruits } \\
\hline Source of variation & df & MS & $F$ & $\mathrm{p}$ & df & MS & $F$ & $\mathrm{p}$ \\
\hline Region & 1 & 270.6547 & 60.97 & 0.001 & 1 & 98.00 & 108.59 & $<0.001$ \\
\hline Reef(Region) & 4 & 4.4392 & 5.42 & 0.003 & 8 & 0.9 & 0.81 & 0.59 \\
\hline Habitat & 1 & 52.5510 & 9.98 & 0.034 & 1 & 46.08 & 62.06 & $<0.001$ \\
\hline Region $\times$ Habitat & 24 & 0.8194 & 0.90 & 0.600 & 1 & 137.78 & 185.56 & $<0.001$ \\
\hline Habitat $\times$ Reef(Region) & 1 & 53.0792 & 10.08 & 0.033 & 8 & 0.74 & 0.66 & 0.72 \\
\hline Chains(Region $\times$ Reef $\times$ Habitat) & 4 & 5.2653 & 6.43 & 0.001 & & & & \\
\hline Residual & 252 & 0.9095 & & & 180 & 1.11 & & \\
\hline SNK tests & $\begin{array}{l}\text { All } \\
\text { All }\end{array}$ & $\begin{array}{l}\text { Habitat } \times \text { Re } \\
\text { reefs at VIL: } \\
\text { eefs at PEN: }\end{array}$ & $\begin{array}{l}\text { ef(Regio } \\
\text { open }=\mathrm{C} \\
\text { open }>\mathrm{C}\end{array}$ & $\begin{array}{l}\text { vice } \\
\text { evice }\end{array}$ & $\begin{array}{l}\text { VIL: of } \\
\text { crevi }\end{array}$ & $\begin{array}{l}\text { Regio } \\
\text { en }>\text { crevic } \\
\text { ce: } \text { PEN > }\end{array}$ & $\begin{array}{l}\text { Habitat } \\
\text { PEN: cre } \\
\text {; open: V }\end{array}$ & $\begin{array}{l}\text { Le > open } \\
\text { L > PEN }\end{array}$ \\
\hline
\end{tabular}

\section{Intensity of herbivory on kelp recruits}

The number of grazing marks on kelp recruits differed between regions and habitats (Fig. $2, \chi^{2}$ region $=$ 193.7, $\chi^{2}$ habitat $=96.3, \mathrm{df}=2, \mathrm{p}<0.001$ ) with a larger number of heavy grazing marks at PEN and in open reef areas compared to VIL and crevices, respectively. Consumption of kelp recruit biomass was strongly influenced by the region and the type of habitat (significant interaction Habitat $\times$ Reef(Region), $\mathrm{p}=0.033$; Cochran's test: $C=0.1281, \mathrm{p}<0.01$ ) (Table 1, Fig. 3). At PEN, the mean biomass consumption was 2.0-3.2 g ww per recruit in open reef habitats relative to $0.5-1.6 \mathrm{~g} \mathrm{ww}$ per recruit in crevices. In contrast, there was a mean consumption of $0.03-0.04 \mathrm{~g}$ ww per recruit in VIL irrespective of the habitat (SNK pairwise comparisons: all reefs at VIL: open = crevice; all reefs at PEN: open $>$ crevice, $p<0.05$ ).

\section{Abundance of macro-grazers}

Although abundances for both sea urchins and herbivorous fishes varied significantly among surveys (Year, $\mathrm{p}<0.05$ for sea urchins and $\mathrm{p}<0.001$ for

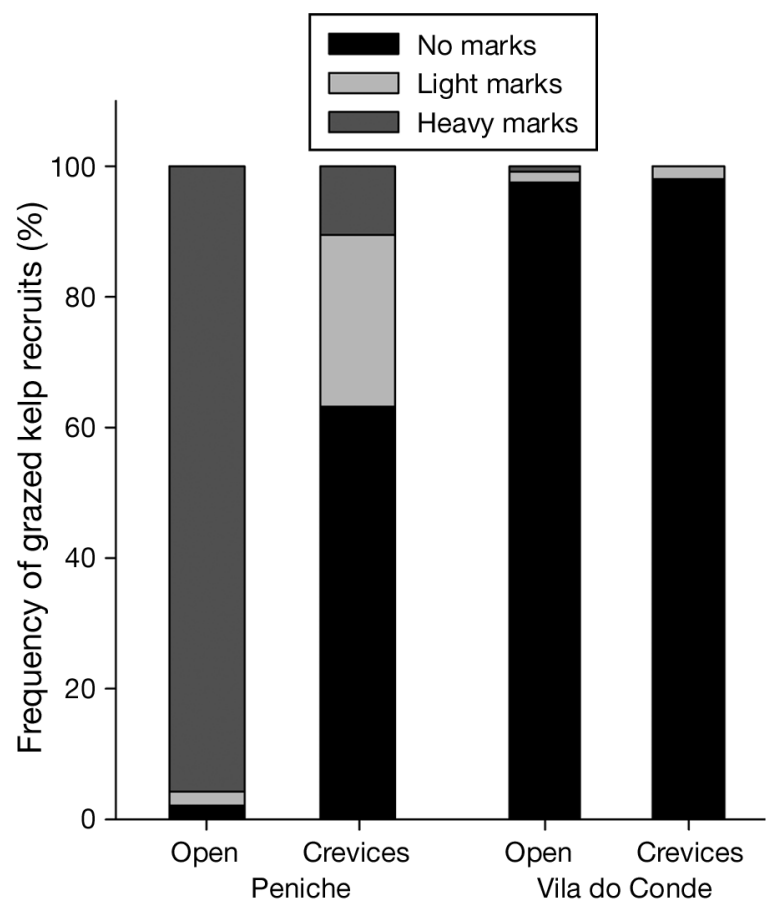

Fig. 2. Frequency and type of grazing marks on kelp recruits ( $\mathrm{n}=234$ ) partitioned by location (Peniche and Vila do Conde, Portugal) and habitat types (open reef and crevices) 


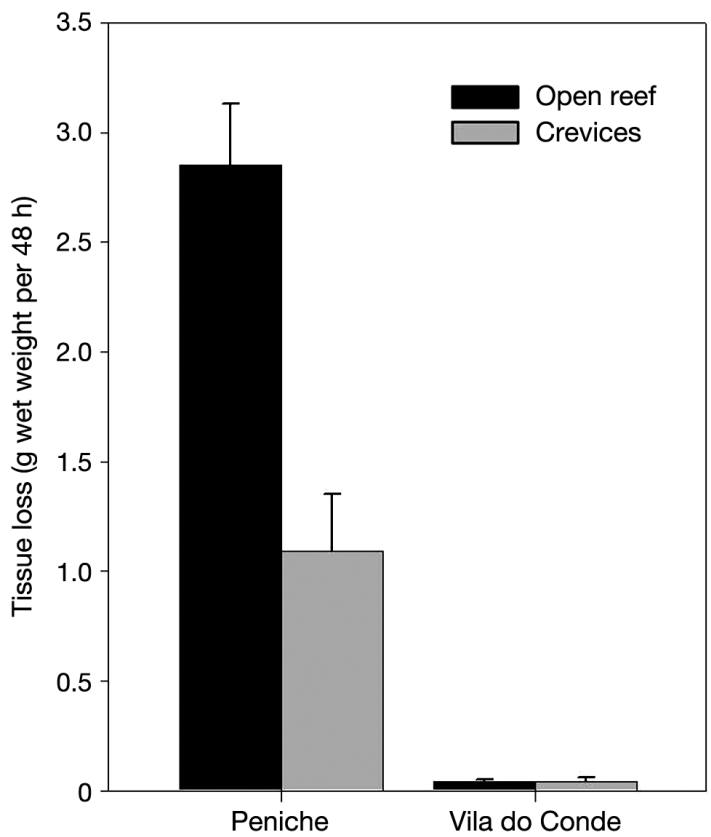

Fig. 3. Consumption of kelp recruits (= tissue loss) in each habitat type (open reef and crevices) at Peniche and Vila do Conde, Portugal (mean $+\mathrm{SE}, \mathrm{n}=48$ )

herbivorous fishes; Table 1, Fig. 4), the abundance of sea urchins was overall ca. 140 times greater at PEN than at VIL (Region, $\mathrm{p}<0.001$; Cochran's test: $C=$ 0.03152) (Table 1, Fig. 4A). From the 19 fish species recorded, only 5 were considered herbivores (Table S1 in the Supplement). The abundance of herbivorous fishes was overall ca. 45 times greater at PEN than at VIL (Region, $\mathrm{p}<0.001$; Cochran's test: $C=$ 0.1462) (Table 1, Fig. 4B).

\section{DISCUSSION}

This study documented a clear difference in the intensity of herbivory on kelp recruits between sites in central and northern Portugal-2 regions with different ocean climate. The differences in intensity of herbivory corresponded to concurrent differences in the abundance of kelp recruits and large-sized herbivores (sea urchins and fishes). Differences in kelp consumption between open reef and crevices further demonstrated how varying herbivory intensity and local topographical features can contribute to spatial heterogeneity in the distribution of kelp recruits.

In central Portugal, kelp recruits were mostly limited to crevices. In contrast, in northern Portugal, kelp recruits also occurred in high abundance in open reef habitats. These differences between

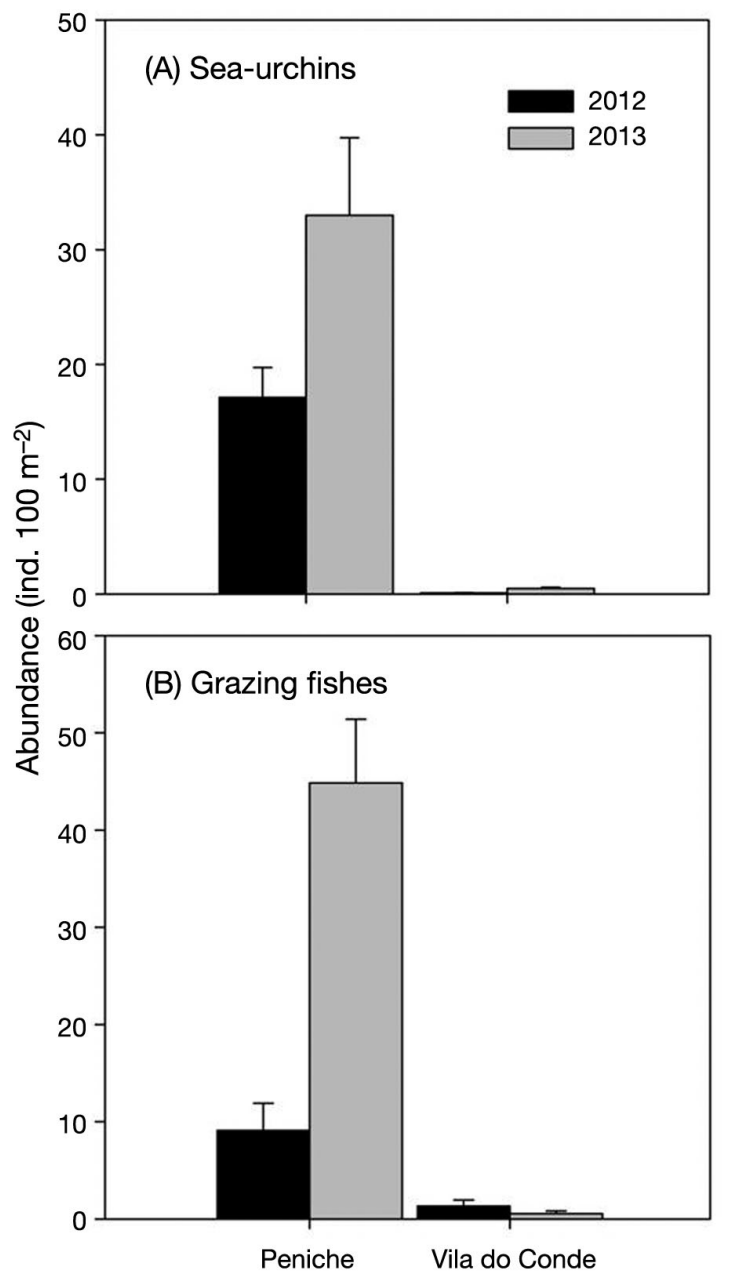

Fig. 4. Abundance of (A) sea urchins and (B) grazing fishes at Peniche and Vila do Conde, Portugal, in 2012 and 2013 $($ mean $+\mathrm{SE}, \mathrm{n}=5)$

regions suggest that strong herbivory pressure in open reef habitats likely suppress the growth of kelp recruits in central Portugal, where kelps recruits only survive when hidden inside crevices. Although crevices are not an ideal micro-habitat for kelp recruitment, e.g. reduced light availability (Bartsch et al. 2008), the need for protection against consumers likely increases their presence in these spatial refuges with localized reduced herbivory, i.e. where large schools of herbivorous fishes do not typically forage. In this sense, topographical refuges likely hinder predation-based mortality (see Milchunas \& Noy-Meir 2002, Fox \& Bellwood 2007). In this study, the distribution of kelp recruits within reefs showed a strong association with high-complexity structural elements (crevices) when grazing was prominent. The capacity of topographic complexity to promote kelp recruitment where herbivores are abundant becomes particularly important in the context of the 
Portuguese coast as the southern range limit of some kelp species, such as Laminaria ochroleuca and Laminaria hyperborea.

In many situations marginal populations are characterized by low densities of adult individuals (Hampe \& Petit 2005), which might lead to a limitation in the supply of propagules (e.g. Bennett \& Wernberg 2014) and so compromise further recruitment. In addition, as demonstrated in this study, recruitment success can be further and drastically compromised by intense herbivory at the range margins. Given that recruits were common in crevices, kelp persistence in central Portugal seems to rely more on avoidance of consumption by herbivores, than on the production of high numbers of spores from adult individuals. In this study, we did not address any potential physiological and/or genetic limitations on kelp distribution, or potential systematic differences in competition with other macroalgae, and the observed patterns of kelp recruit abundance likely reflects the cumulative effects of all biotic and abiotic influences. However, short-term physiological experiments suggest kelp recruits of both L. ochroleuca and Saccorhiza polyschides are capable of physiologically adjusting their metabolic processes (photosynthesis and respiration) to prevailing sea water temperatures in the study region (Biskup et al. 2014). Still, we cannot rule out a possible physiological influence resulting from varying ocean climates between regions, as physiological changes are often manifested through subtle, longterm responses to sublethal stress (abiotic conditions, e.g. Wernberg et al. 2010).

Despite the relatively small gradient in latitude (ca. $2^{\circ}$ ), an abrupt macroecological change in the diversity and structure of shallow-water subtidal assemblages was recently reported between central and northern Portugal (Tuya et al. 2012, Pinho et al. 2015). This is, to some extent, supported by the findings of this study, even though it was not specifically aimed at addressing such issues. The abundance of herbivorous fishes followed a sharp latitudinal cline, as those described for the western Atlantic (Floeter et al. 2005), New Zealand, Australia and the Caribbean (Meekan \& Choat 1997), where the abundance of herbivorous fishes decreased towards latitudes with cooler conditions. At sites in central Portugal, herbivorous fishes were numerically dominated by the genus Diplodus, particularly D. vulgaris and D. sargus, which are recognized as having a generalist feeding behavior (Sala \& Ballesteros 1997, Horta et al. 2004). The diet of these species is typically omnivorous, including invertebrates and algae, the latter with a frequency of occurrence typically between 30 and $56 \%$ (Sala \& Zabala 1996). Sarpa salpa is the only obligate herbivorous fish in continental Portugal. This species is an ecologically important macrograzer in the Mediterranean (Vergés et al. 2009), particularly when occurring in schools of several hundreds of individuals (Verlaque 1990). While common in central Portugal, this species is normally found in very low abundances in northern Portugal (Rodrigues et al. 2011, Henriques et al. 2013, this study). Hence, although we do not have unambiguous evidence, it is likely that this species is responsible for a large part of the consumption of kelp recruits in central Portugal.

The sea urchin Paracentrotus lividus displayed the same pattern of abundance as herbivorous fishes, being noticeably more abundant in central than in northern Portugal. In addition, predator effects on behavior of this echinoid may also contribute to reduced grazing at the northern Portugal site in connection with the high densities of the predatory starfish Marthasterias glacialis found on rocky reefs in northern Portugal (Tuya \& Duarte 2011). Although mussels are the preferred prey of Marthasterias glacialis (Tuya \& Duarte 2011), the presence of this starfish might induce indirect effects on sea urchins. Predators that are continuously present in a particular habitat may provide persistent cues to alter the behavior of potential prey, including a reduction in their foraging area (Schmitz et al. 2004). However, sea urchin behavior can vary due to species-specific traits (Andrew 1993) and habitat heterogeneity; the latter has been documented to increase grazing pressure, possibly because nearby crevices can act as urchin refugia (Andrew 1993, Benedetti-Cecchi \& Cinelli 1995). In this study, sea urchins seem to have a minor overall influence on kelp recruits regardless of the region, due to the low number of sea urchin bite marks compared to fishes. This is an interesting finding since the majority of studies regarding herbivory on kelps are associated with sea urchin grazing, and not with fish grazing. Although we cannot ascertain for sure that bite marks on kelp recruits were exclusively from fishes, the methods used allowed equal exposure of kelps to both fishes and sea urchins and the vast majority of kelp recruits showed bite marks consistent with fish herbivory (Fig. S1a,b in the Supplement).

The regional differences in herbivory on kelp recruits demonstrated in this study matches the inverse pattern of abundance of adult kelps across continental Portugal (Tuya et al. 2012, Pinho et al. 2015). Previously, the presence and fitness of kelps across southern European waters had been exclu- 
sively linked to bottom-up and climatic influences (Lüning 1990, Bartsch et al. 2008, Fernández 2011). Our results highlight that herbivory might also play a role by affecting the survivorship of kelp recruits towards their southern distribution limit in continental Portugal. Moreover, increasing sea water temperatures are expected to increase the arrival and spread of herbivores, and will likely increase consumer pressure on recipient macroalgal assemblages at temperate latitudes (Vergés et al. 2014, Bennett et al. 2015). In this context, reports on the presence of new herbivorous species across southern Europeincluding records of species with tropical affinities located northwards of their usual distribution range, and also including herbivorous fishes (Canas et al. 2005, Abecasis et al. 2009) — have been increasingly frequent across the Iberian Peninsula during the last decade (Bañón \& Mucientes 2009, Rodrigues 2012).

While no long-term quantitative data exist, anecdotal evidence from central Portugal suggests that kelp beds were abundant in this region in the past (Assis et al. 2009). At present, we cannot say for sure if the apparent loss of kelp beds in the region is permanent. However, our results suggest that reestablishment is unlikely, or at best will be very slow, as long as herbivore pressure remains intense in open reef habitats.

Acknowledgements. Financial support was provided by the European Regional Development Fund (ERDF) through the 'Programa Operacional Factores de Competitividade' (POFCCOMPETE) within the Quadro de Referência Estratégico Nacional (QREN) and the Portuguese Fundação para a Ciência e a Tecnologia (FCT) through the projects 'Efeitos do clima oceânico na macroecologia e resiliência a perturbações dos povoamentos de kelps' - OCEANKELP (PTDC/MAR/109954/ 2009) and PEst-C/MAR/LA0015/2011 and a PhD grant (SFRH/ BD/84933/2012) to J.N.F. F.T was supported by the MINECO Ramón y Cajal' program, T.W. by the Australian Research Council and I.B. by FCT within the Programa Ciência 2008 Fundo Social Europeu. We are very grateful to A. Vergés for comments and suggestions and M. Ramos for her help with field work. Our thanks also go to Prof. P. Maranhão and Escola Superior de Tecnologias do Mar - Instituto Politecnico de Leiria (ESTM-IPL) who generously provided logistic support in Peniche. All the authors have no conflict of interest to declare.

\section{LITERATURE CITED}

Abecasis D, Bentes L, Ribeiro J, Machado D and others (2009) First record of the Mediterranean parrotfish, Sparisoma cretense in Ria Formosa (south Portugal). Mar Biodivers Rec 1:1-2

Andrew N (1993) Spatial heterogeneity, sea urchin grazing, and habitat structure on reefs in temperate Australia. Ecology 74:292-302

Assis J, Tavares D, Tavares J, Cunha A (2009) Findkelp, a
GIS-based community participation project to assess Portuguese kelp conservation status. J Coast Res 3:1469-1473

Bañón R, Mucientes G (2009) First record of Seriola fasciata (Carangidae) from Galician waters (NW Spain). A new northernmost occurrence in the NE Atlantic. Cybium 33: 247-248

Bartsch I, Wiencke C, Bischof K, Buchholz CM and others (2008) The genus Laminaria sensu lato: recent insights and developments. Eur J Phycol 43:1-86

Benedetti-Cecchi L, Cinelli F (1995) Habitat heterogeneity, sea urchin grazing and the distribution of algae in littoral rock pools on the west coast of Italy (western Mediterranean). Mar Ecol Prog Ser 126:203-212

Bennett S, Wernberg T (2014) Canopy facilitates seaweed recruitment on subtidal temperate reefs. J Ecol 102: 1462-1470

Bennett S, Wernberg T, Harvey ES, Santana-Garcon J, Saunders BJ (2015) Tropical herbivores provide resilience to a climate-mediated phase shift on temperate reefs. Ecol Lett 18:714-723

Bergey EA (2005) How protective are refuges? Quantifying algal protection in rock crevices. Freshw Biol 50:1163-1177

- Bertocci I, Seabra MI, Dominguez R, Jacinto D, Ramírez R, Coca J, Tuya F (2014) Effects of loss of algal canopies along temperature and irradiation gradients in continental Portugal and the Canary Islands. Mar Ecol Prog Ser 506:47-60

Biskup S, Bertocci I, Arenas F, Tuya F (2014) Functional responses of juvenile kelps, Laminaria ochroleuca and Saccorhiza polyschides, to increasing temperatures. Aquat Bot 113:117-122

Bolser R, Hay M (1996) Are tropical plants better defended? Palatability and defenses of temperate vs. tropical seaweeds. Ecology 77:2269-2286

Brandl SJ, Hoey AS, Bellwood DR (2014) Micro-topography mediates interactions between corals, algae, and herbivorous fishes on coral reefs. Coral Reefs 33:421-430

Brown J, Gillooly J, Allen A, Savage V, West G (2004) Toward a metabolic theory of ecology. Ecology 85:1771-1789

> Cahill AE, Aiello-Lammens ME, Caitlin Fisher-Reid M, Hua $\mathrm{X}$ and others (2014) Causes of warm-edge range limits: systematic review, proximate factors and implications for climate change. J Biogeogr 41:429-442

Canas A, Vasconcelos P, Lino PG, Santos MN (2005) Northernmost record of Kyphosus sectator (Osteichthyes: Perciformes: Kyphosidae) in the north-eastern Atlantic. J Mar Biol Assoc UK 85:1535-1537

Craft JD, Paul VJ, Sotka EE (2013) Biogeographic and phylogenetic effects on feeding resistance of generalist herbivores toward plant chemical defenses. Ecology 94: $18-24$

> Cyr H, Pace ML (1993) Magnitude and patterns of herbivory in aquatic and terrestrial ecosystems. Nature 361:148-150

$>$ de Bettignies T, Wernberg T, Lavery PS, Vanderklift MA, Mohring MB (2013) Contrasting mechanisms of dislodgement and erosion contribute to production of kelp detritus. Limnol Oceanogr 58:1680-1688

$>$ Fernández C (2011) The retreat of large brown seaweeds on the north coast of Spain: the case of Saccorhiza polyschides. Eur J Phycol 46:352-360

> Floeter SR, Behrens MD, Ferreira CEL, Paddack MJ, Horn $\mathrm{MH}$ (2005) Geographical gradients of marine herbivorous fishes: patterns and processes. Mar Biol 147:1435-1447

Fox R, Bellwood D (2007) Quantifying herbivory across a coral reef depth gradient. Mar Ecol Prog Ser 339:49-59

Gaines S, Lubchenco J (1982) A unified approach to marine plant-herbivore interactions. II. Biogeography. Annu Rev 
Ecol Syst 13:111-138

Hampe A, Petit RJ (2005) Conserving biodiversity under climate change: the rear edge matters. Ecol Lett 8:461-467

Henriques S, Pais MP, Costa MJ, Cabral HN (2013) Seasonal variability of rocky reef fish assemblages: detecting functional and structural changes due to fishing effects. J Sea Res 79:50-59

Horta M, Costa MJ, Cabral H (2004) Spatial and trophic niche overlap between Diplodus bellottii and Diplodus vulgaris in the Tagus estuary, Portugal. J Mar Biol Assoc UK 84:837-842

Jacinto D, Bulleri F, Benedetti-Cecchi L, Cruz T (2013) Patterns of abundance, population size structure and microhabitat usage of Paracentrotus lividus (Echinodermata: Echinoidea) in SW Portugal and NW Italy. Mar Biol 160: 1135-1146

Levenbach S (2009) Grazing intensity influences the strength of an associational refuge on temperate reefs. Oecologia 159:181-190

Lima FP, Ribeiro PA, Queiroz N, Hawkins SJ, Santos AM (2007) Do distributional shifts of northern and southern species of algae match the warming pattern? Glob Change Biol 13:2592-2604

Ling SD, Ibbott S, Sanderson JC (2010) Recovery of canopyforming macroalgae following removal of the enigmatic grazing sea urchin Heliocidaris erythrogramma. J Exp Mar Biol Ecol 395:135-146

Lüning K (1990) Seaweeds: their environment, biogeography, and ecophysiology. Wiley, New York, NY

Meekan MG, Choat JH (1997) Latitudinal variation in abundance of herbivorous fishes: a comparison of temperate and tropical reefs. Mar Biol 128:373-383

Milchunas D, Noy-Meir I (2002) Grazing refuges, external avoidance of herbivory and plant diversity. Oikos 99: $113-130$

Moles AT, Bonser SP, Poore AGB, Wallis IR, Foley WJ (2011) Assessing the evidence for latitudinal gradients in plant defence and herbivory. Funct Ecol 25:380-388

Pinho D, Bertocci I, Arenas F, Franco JN and others (2015) Spatial and temporal variation of kelp forests and associated macroalgal assemblages along the Portuguese coast. Mar Freshw Res, doi:10.1071/MF14318

> Poore AGB, Campbell AH, Coleman RA, Edgar GJ and others (2012) Global patterns in the impact of marine herbivores on benthic primary producers. Ecol Lett 15:912-922

Reader R (1992) Herbivory, competition, plant mortality and reproduction on a topographic gradient in an abandoned pasture. Oikos 65:414-418

Rodrigues NV (2012) New geographic distribution records for Northeastern Atlantic species from Peniche and Berlengas Archipelago. Arquipélago Life Mar Sci 29:1-4

Rodrigues NV, Mendes S, Franco JN, Castanheira M, Castro N, Maranhão P (2011) Fish diversity in the Berlengas Natural Reserve (Portugal), a marine protected area. Ecologi 43:35-43

Sala E, Ballesteros E (1997) Partitioning of space and food resources by 3 fish of the genus Diplodus (Sparidae) in a Mediterranean rocky infralittoral ecosystem. Mar Ecol Prog Ser 152:273-283

Sala E, Zabala M (1996) Fish predation and the structure of the sea urchin Paracentrotus lividus populations in the NW Mediterranean. Mar Ecol Prog Ser 140:71-81

Schemske DW, Mittelbach GG, Cornell HV, Sobel JM, Roy $\mathrm{K}$ (2009) Is there a latitudinal gradient in the impor- tance of biotic interactions? Annu Rev Ecol Evol Syst 40: 245-269

Schmitz OJ, Krivan V, Ovadia O (2004) Trophic cascades: the primacy of trait-mediated indirect interactions. Ecol Lett 7:153-163

Sedell J, Reeves G, Hauer F, Stanford JA, Hawkins CP (1990) Role of refugia in recovery from disturbances: modern fragmented and disconnected river systems. Environ Manag 14:711-724

Shurin J, Borer E, Seabloom E, Anderson K and others (2002) A cross-ecosystem comparison of the strength of trophic cascades. Ecol Lett 5:785-791

Stachowicz JJ, Bruno JF, Duffy JE (2007) Understanding the effects of marine biodiversity on communities and ecosystems. Annu Rev Ecol Evol Syst 38:739-766

> Steneck RS, Graham MH, Bourque BJ, Corbett D, Erlandson JM, Estes JA, Tegner MJ (2002) Kelp forest ecosystems: biodiversity, stability, resilience and future. Environ Conserv 29:436-459

Toohey BD, Kendrick GA, Harvey ES (2007) Disturbance and reef topography maintain high local diversity in Ecklonia radiata kelp forests. Oikos 116:1618-1630

Tuya F, Duarte P (2011) Role of food availability in the bathymetric distribution of the starfish Marthasterias glacialis (Lamk.) on reefs of northern Portugal. Sci Mar 76:9-15

Tuya F, Wernberg T, Thomsen MS (2011) The relative influence of local to regional drivers of variation in reef fishes. J Fish Biol 79:217-234

> Tuya F, Cacabelos E, Duarte P, Jacinto D and others (2012) Patterns of landscape and assemblage structure along a latitudinal gradient in ocean climate. Mar Ecol Prog Ser 466:9-19

Underwood A (1980) The effects of grazing by gastropods and physical factors on the upper limits of distribution of intertidal macroalgae. Oecologia 46:201-213

Underwood AJ (1997) Experiments in ecology: their logical design and interpretation using analysis of variance. Cambridge University Press, Cambridge

Vanderklift MA, Kendrick GA (2004) Variation in abundances of herbivorous invertebrates in temperate subtidal rocky reef habitats. Mar Freshw Res 55:93-103

> Vergés A, Alcoverro T, Ballesteros E (2009) Role of fish herbivory in structuring the vertical distribution of canopy algae Cystoseira spp. in the Mediterranean sea. Mar Ecol Prog Ser 375:1-11

Vergés A, Steinberg P, Hay ME, Poore AG and others (2014) The tropicalization of temperate marine ecosystems: climate-mediated changes in herbivory and community phase shifts. Proc R Soc B 281:20140846

Verlaque M (1990) Relations entre Sarpa salpa (Linnaeus, 1758) (Téléostéen, Sparidae), les autres poissons brouteurs et le phytobenthos algal méditerranéen. Oceanol Acta 13:373-388

> Wernberg T, Vanderklift MA, How J, Lavery PS (2006) Export of detached macroalgae from reefs to adjacent seagrass beds. Oecologia 147:692-701

Wernberg T, Thomsen MS, Tuya F, Kendrick GA, Staehr PA, Toohey BD (2010) Decreasing resilience of kelp beds along a latitudinal temperature gradient: potential implications for a warmer future. Ecol Lett 13:685-694

Wernberg T, Smale DA, Tuya F, Thomsen MS and others (2013) An extreme climatic event alters marine ecosystem structure in a global biodiversity hotspot. Nat Clim Change 5:1-5 